\title{
Taking Up the Cudgels Against Gay Rights? Trends and Trajectories in African Christian Theologies on Homosexuality
}

\author{
ADRIAAN S. VAN KLINKEN, PhD \\ Department of the Study of Religions, School of Oriental and African Studies, \\ University of London, London, UK \\ MASIIWA RAGIES GUNDA, PhD \\ Department of Religious Studies, Classics and Philosophy, University \\ of Zimbabwe, Zimbabwe
}

\begin{abstract}
Against the background of the HIV epidemic and the intense public controversy on homosexuality in African societies, this article investigates the discourses of academic African Christian theologians on homosexuality. Distinguishing some major strands in African theology, that is, inculturation, liberation, women's and reconstruction theology, the article examines how the central concepts of culture, liberation, justice, and human rights function in these discourses. On the basis of a qualitative analysis of a large number of publications, the article shows that stances of African theologians are varying from silence and rejection to acceptance. Although many African theologians have taken up the cudgels against gay rights, some "dissident voices" break the taboo and develop more inclusive concepts of Africanidentity and African Christianity.
\end{abstract}

KEYWORDS homosexuality, Africa, theology, Christianity, postcolonial identity politics

The authors thank the anonymous peer reviewers of this journal whose critical comments and helpful suggestions have helped to improve this article. 


\section{INTRODUCTION}

Everyone following the news will know that in contemporary African societies, the topic of homosexuality raises much controversy. One just has to call to mind the murder of the prominent Ugandan gay rights activist David Kato in January 2011, some months after a national newspaper published a list with "top homosexuals" alongside a banner reading "Hang Them." Other illustrations are the ongoing public and political debate in Uganda about the Anti-Homosexual Bill that imposes the death penalty on people involved in same-sex practices, or the case of the two Malawian men who, in May 2010, were jailed for 14 years because of homosexuality-related offenses and that were pardoned by the country's president only after the intervention of United Nations Secretary General, Ban Ki Moon. In African public debates, homosexuality often is rejected with a reference to tradition or culture. For example, the President of Malawi, making the declaration that he had pardoned the two gay men, yet stated that "These boys committed a crime against our culture, our religion and our laws" (Bearak, 2010). A popular view in many African societies holds that homosexuality is un-African and is a Western invention, in spite of historians and anthropologists providing evidence of precolonial forms of same-sex patterns (Epprecht, 1998; Murray \& Roscoe, 1998). The endurance and reproduction of this myth is considered to show that the controversy on homosexuality has become part of African postcolonial identity politics in our globalizing world (Hoad, 2007).

It is often said that, in Africa, religious belief has a huge impact on public debates and politics, and religious organizations play a crucial role in shaping these debates and politics (cf. Englund, 2011; Gifford, 2009). An important question, then, concerns the role of religion in the controversy on homosexuality in postcolonial African societies. As far as Christianity is concerned, the role of religious organizations and their leaders is clearly demonstrated in the debate on homosexuality in the global Anglican Communion, where a number of African Anglican bishops are leading the opposition against the ordination of homosexual priests and the blessing of same-sex marriages in American member churches (Hassett, 2007; Ward, 2002). Moreover, in public and political discourses on homosexuality in African societies, the Bible is found to play a major role (Gunda, 2010). Given the controversy surrounding homosexuality and the role of Christianity in this debate, it is important to identify the various voices and arguments. This is an urgent task, not only for the study of African Christianity, but also for the study of world Christianity where homosexuality is causing a huge chasm (Jenkins, 2007).

Rather than in African religious or Christian discourses on homosexuality in general, in this article, our interest is in a specific type of Christian discourse, being the voices of African Christian theologians. This interest was aroused by our reading of a recent publication on homosexuality in Africa, the book Heterosexual Africa? The History of an Idea from the Age of Exploration to the Age of AIDS (Epprecht, 2008). In this study, Epprecht argues that in historical and contemporary discourses, a singular, heterosexual identity of Africa is constructed. As part of the argument, he makes the general statement that also "African theologians have taken up the cudgels 
against gay rights" (p. 32). Epprecht does not elaborate on his statement. He only refers broadly to Christian fundamentalists in Uganda who, supported by American evangelicals, have influenced AIDS campaigns in their country to promote abstinence rather than condoms and who propagate "harmful stereotypes and silences concerning sexuality" (p. 32). Although any African religious leader somehow can be considered an African theologian, it is inaccurate to take some evangelical fundamentalist leaders in Uganda as representatives of African theologians. As we will demonstrate in this article, the category of African theologians, or even African Christian theologians, is too broad and diverse to make any general statement about African theologians and their views on homosexuality.

In this article, we focus on a specific group of African Christian theologians, being professional theologians who are academically trained and are working in the field of African theology. To describe African theology is a very difficult and complex task (Frederiks \& Mashau, 2008), but the term as we use it refers to a cluster of Christian theologies developed by professional/academic theologians who reflect on the Christian faith in relation to the historical, social and cultural realities of African societies (cf. Bujo \& Muya, 2003, 2006; Maluleke, 2005). We are aware that the theological scholars who are involved in this type of African theology may be part of an intellectual elite and are not representative of African Christians or African theologians in general. However, especially because they are part of an intellectual elite and because they often have influential positions in centers of theological education and contribute to public debates, we are interested in the question whether these theologians are talking about homosexuality, and, if so, whether they fit or do not fit in Epprecht's (2008) representation of African theologians taking up the cudgels against gay rights. Investigating this question, we take into account that African theology is not a monolithic whole. Different strands of African theology can be distinguished on the basis of their different theoretical and methodological frameworks. Our hypothesis is that depending on these different strands of African theology, there already may exist different trends and trajectories in the manner homosexuality has been dealt with by African theologians. This hypothesis is confirmed by Epprecht (2008) himself when he acknowledges the work of at least one African Christian leader and theologian, Desmond Tutu, who clearly has taken up cudgels for gay rights in Africa.

In the following section, we introduce the major strands generally distinguished in African theology and further define our analytical questions. The greater part of this article is devoted to an analysis of the discourses of African theologians on homosexuality, analyzing discourses that keep silent on the topic, discourses that oppose and reject it, and discourses representing more tolerant voices. In the final section, we draw out some conclusions on the trends and trajectories in African Christian theological discussions on homosexuality. 


\section{AFRICAN THEOLOGIES}

As mentioned above, in this article we have a specific understanding of African theology. First, we insist on referring to African Christian theology, making a distinction from theologies emanating from other religions on the African continent. Second, we refer to African Christian theologies in the plural, to indicate the existence of a multiplicity of Christian conceptions of God on the African continent. Third, we refer specifically to African theology as an enterprise of professional theologians who often have been trained and are working in academic settings. In literature on African theology, often the following major strands are distinguished, although their considerable overlapping is also acknowledged: African inculturation theology, African liberation theology, African women's theology, and African reconstruction theology. What are the characteristics of these trajectories and what specific questions do these raise concerning the manner the issue of homosexuality is addressed within these different paradigms?

Inculturation theology is a very prominent strand of African theology. It seeks to develop a Christianity with an African face, that is, a type of Christianity that (re)values African cultural and religious traditions positively (though critically) and seeks to incorporate them in expressions of the Christian faith that are authentically African (cf. Magesa, 2004). As a response to the colonial denigration of African traditions, inculturation theology can be considered a theological expression of the postcolonial quest for African identity and African Christian selfunderstanding (Antonio, 2006). As mentioned briefly above, in African postcolonial identity politics, homosexuality is often portrayed as a Western invention in spite of evidence of indigenous forms of homosexuality in Africa. This raises the question as to how theologians working in the paradigm of inculturation theology deal with the issue of homosexuality and how they relate to the identity politics played on this issue.

African theology has often been categorized in a twofold scheme of inculturation and liberation theology (Martey, 1993). Indeed, African liberation theology, and its Southern African counterpart Black theology, form a major strand in African theology. Rather than with the category of African culture, liberation and Black theology are mainly concerned with social-political categories. In their high days, theologians working in these paradigms opposed colonization and apartheid. In more recent times, liberation theologians have come to address issues such as poverty, globalization, and HIV and AIDS. Questions of human rights and justice are part and parcel of the African theological discourses in the paradigm of liberation (e.g., Phiri, 2004b). The primary concern of African liberation theology has been White and Western socioeconomic and political oppression of Africa. However, as Martey (2000) indicates, liberation theology also is "a response to oppressions of Africans by Africans" (p. 127). He concretely refers to the oppression of women, but in this time and age the question arises whether it may also include the oppression of people identifying (or identified) as homosexuals in Africa.

African women theologians are largely engaged in the paradigm of 
liberation theology. Well organized in the Circle of Concerned African Women Theologians, African women's theology has become a third and influential strand in African theology. It is characterized by a focus on the category of gender. African women theologians critically address women's issues in African societies, cultures, and religions, and they persistently call for the liberation of women and for gender equality (cf. Oduyoye, 2001). They share the quest for African Christian self-understanding, but their critique is that inculturation theologians are not sensitive to the patriarchal oppression in the African cultural traditions they seek to reclaim (Mutambara, 2006). In the last decade, African women theologians have been in the forefront of discussing issues of gender and sexuality in relation to the HIV epidemic, and they have developed progressive theologies of gender justice (Dube \& Kanyoro, 2004; Phiri, Haddad, \& Masenya, 2003). A key question, then, is whether they also have addressed the issue of homosexuality in a progressive way.

The fourth and last strand in African theology mentioned here is reconstruction theology. Where liberation and Black theology are rooted in the opposition of colonialism and apartheid, reconstruction theology aims to contribute constructively to the building of postcolonial African societies and nations (Mugambi 1995, 2003). A major representative of this theology, South African theologian Charles Villa-Vicencio, has built his account on a theology of human rights, which he specifically applies on the categories of race and gender (VillaVicencio, 1992). The question is whether the same approach is applied to the category of sexuality. Does reconstruction theology seek to promote a social and political space for those identifying as homosexuals, lesbians, and bisexuals in postcolonial African societies?

In our investigation of African theological discourses on homosexuality, we particularly take into account two aspects of the social context of these discourses. First, we attend to the current sociopolitical context of many African societies, where homosexuality has become a central topic in postcolonial identity politics vis-à-vis the West. Against this background, the question how homosexuality is addressed by African theologians is a relevant one. Second, this question becomes even more important in light of another social reality in sub-Saharan Africa: the HIV epidemic. As mentioned above, numerous African theologians - and in particular African women theologians - have engaged in a theological response to the epidemic (cf. Frederiks, 2008; van Klinken, 2011). As part of this response, they have addressed issues of gender and sexuality in progressive ways, breaking the cultural taboos on talking about these issues. As will be outlined below, a major argument of Epprecht (2008) is that the possible homosexual transmission of HIV is often ignored, both in Western and African discourses on HIV and AIDS in subSaharan Africa. Engaging this argument, we ask whether African theologians, in their responses to the HIV epidemic, engage in the assumption of a strict heterosexual sexual transmission of HIV or whether they have seized the epidemic as an opportunity to tackle the subject of homosexualities in Africa. 


\section{RESEARCH QUESTION AND METHOD}

Before starting to investigate the discourses of African theologians on homosexuality, we will recapture and further define the research question central in this article and explain our methodological approach.

Thus far, we have shown that African liberation, and African women's and reconstruction theologies are characterized by a commitment to justice, human liberation, and human rights in African socioeconomic and political contexts. Theologians working in the field of inculturation theology may share this commitment (as there is much overlap between the strands of African theology distinguished above), but their basic concern is with questions of cultural and religious identity rather than with socioeconomic issues. Our general question as to how homosexuality is addressed in African theologies, then, can be specified. With regard to liberation, women's and reconstruction theologies, the question is whether the commitment to justice, liberation, and human rights does have impact on the theological discourses on and stances toward homosexuality. This question is particularly relevant as in Western discourses, including liberal theological discourses in the West, the issue of homosexuality is often presented as a human rights and justice issue. Do some African theologians share this understanding? Do they subsequently demonstrate more tolerant attitudes towards homosexuality and oppose the anti-homosexual popular rhetoric heard in African societies today? Have they come to defend the rights of sexual minorities and embraced sexual diversity? With regard to inculturation theology, the question can be defined as to how the appraisal of African culture functions in theological discourses on homosexuality. Do theologians working in the paradigm of inculturation theology employ a static and heteronormative concept of African culture, and related to that also a heteronormative understanding of the Christian faith, or do they acknowledge that same-sex relationships have occurred in precolonial African societies and exist in contemporary African societies and do they hence develop more inclusive concepts of African culture as well as of African Christianity? In this article, then, our central question is how the central concepts of culture, liberation, justice, and human rights do function in African theological discourses on homosexuality from the strands of inculturation, liberation, women's, and reconstruction theologies, and whether the possible differences in the way homosexuality is addressed can be explained in relation to these different strands.

We assume that Epprecht's (2008) observation of African theologians taking up the cudgels against gay rights can be substantiated, but we also think that the observation can be nuanced and differentiated on the basis of a cross-section survey of African theological discourses. In this article, we undertake such a survey, analyzing a wide range of publications of African theologians in which reference is made to homosexuality. Our analyses are qualitative. While we have tried to work with as many publications as possible, we do not have any pretention of completeness. We have opted for a basic categorization of the discourses under discussion. The first category consists of publications where homosexuality is opposed and contested explicitly. The second category consists 
of publications taking a more tolerant stance toward homosexuality, or even defending the rights of sexual minorities explicitly. Keeping in mind Epprecht's argument that silence on homosexuality is a major indication of heteronormativity, a third category of publications can be distinguished: those who keep silent on the topic. Obviously, most publications of African theologians fit in this category, as homosexuality is far from a major issue in African theology. However, we agree with Epprecht that, particularly in the discourse on HIV and AIDS, this silence is significant. Therefore, we first pay attention to African theological publications on the HIV epidemic, which indeed largely keep silent about homosexuality or deliberately avoid it.

\section{SILENCE ON HOMOSEXUALITY: THE ASSUMPTION OF HETEROSEXUAL AIDS}

A major argument in Epprecht's (2008) book is how HIV in Africa has been discursively constructed as a heterosexual epidemic. A "commonplace false assumption" of AIDS researchers was, according to Epprecht "that if a man was married to a woman or went to female prostitutes, then he was heterosexual" ( $p$. 112). Researchers took heterosexuality as a stable category, meaning that men were assumed to be exclusively and permanently heterosexual when they indicated to have had sexual relations with women. Some recent studies draw attention to the fact that the sexual behavior of men who have sex with men in Africa often is not exclusively homosexual (Phillips, 2004). From that perspective, the United Nations Programme on HIV/AIDS statistics indicating that the levels of HIV infection among men having sex with men are very high, are also relevant with regard to the heterosexual transmission of the virus. ${ }^{1}$ Yet, the idea that homosexuality is irrelevant to HIV transmission in Africa is pervasive, as Epprecht points out. He does not explain this primarily from homophobia of the researchers but rather from their heteronormative perceptions of African sexuality.

As mentioned above, many African theologians are engaged in a response to the HIV epidemic. They consider the epidemic as a major challenge to churches and to theology in Africa, and they have addressed critical issues concerning stigma, gender, etc (Maluleke, 2001b). Most theologians, however, have not touched on the issue of homosexuality in relation to HIV. Even a leading scholar in the area of theology and HIV and AIDS, like Isabel Phiri does not consider homosexuality a relevant issue in view of HIV. According to Phiri (2004a), "[w]hile in Europe and America the spread of HIV is mainly through homosexual relationships, in Africa it is predominantly through heterosexual multiple relationships" (p. 424). Hence, Phiri's publications on HIV and AIDS, which particularly focus on the gendered dimensions of the epidemic, do not pay attention to homosexuality. Phiri and other women theologians consider married women to be at high risk to HIV, because many husbands would engage in multiple sexual relations (Phiri 2003). But, generally, they do not consider it an 
option that some of men's possible multiple partners could be male, as they understand heterosexuality as an exclusive category. ${ }^{2}$ Epprecht's (2008) argument on HIV in Africa being constructed as a heterosexual epidemic can be further illustrated with Ezra Chitando, who is also a leading scholar in the theological response to HIV and AIDS. According to Chitando (2007), the HIV epidemic has provided churches in Africa an opportunity to discuss sexuality in an "open and liberating way" (p. 33). In his opinion, churches have great difficulty doing so because of several historical and theological reasons. Chitando says that this difficulty "is a major limitation given that heterosexual transmission lies behind the rapid spread of HIV in Africa" (p. 33). This phrase is significant because it suggests that Chitando, even though he underscores the need to discuss sexuality openly and progressively, apparently only thinks of sexuality and HIV in terms of heterosexuality. Chitando's own limitation is critical, especially as he is in the forefront of discussions on men and masculinities in relation to HIV. He critically deconstructs hegemonic masculinities as these would contribute to the spread of HIV and would affect negatively women's and children's lives, and he proposes a vision for alternative masculinities that meet the criterion of gender justice (Chitando, 2008; Chitando \& Chirongoma, 2008). However, it seems that his critical analysis and his constructive vision are confined to heterosexuality. We do not attribute this to homophobia but rather to the general assumption of HIV being a heterosexual epidemic in Africa and the subsequent neglect of a possible homosexual transmission of the virus. It is our observation that most African theologians addressing the HIV epidemic seem to accept this idea uncritically.

\section{Strategic Silences}

Apart from the heterosexual assumptions about HIV in Africa, there seem to be strategic reasons for African theologians working on issues of HIV and AIDS to keep silent about homosexuality. South African theologian Ronald Nicolson (2000), who, in 1996 published the book God in AIDS?, responded a few years later to the critique from European scholars that he did not discuss homosexuality. Admitting that the criticisms are justified, he not only says that "in Africa, of course, homosexuality is largely irrelevant to the AIDS crisis," (p.10) but he also makes another significant comment. He explains that those who want to break the taboo on HIV and AIDS within the churches walk a fine line: "If we vociferously challenge the traditional Christian ethics about sex outside of marriage or about contraception or about homosexuality, we risk alienating the churches and thus making it less likely that churches will become involved in the struggle against AIDS" (p. 12). The latter statement is crucial, because it indicates that homosexuality - even if it is relevant to HIV in Africa - is not likely to be discussed by theologians because the issue is considered too controversial. This consideration is understandable in light of the popular anti-homosexual rhetoric among Christians and church leaders in Africa. It is clear, therefore, that some of the silences by African theologians are an attempt to avoid complicating the fight against HIV.

Another strategic reason may be related with the stigma surrounding the HIV 
epidemic. In Africa, the initial association of AIDS with homosexuality has contributed enormously to the stigmatization of people living with HIV (cf. Frederiks, 2008). Stigmatization has been a major concern of the African theologians who engage with the epidemic (Chitando \& Gunda 2007). Emphasizing the heterosexual transmission of the virus may have been a deliberate attempt to avoid the association of HIV with homosexuality and, thus, to break down the stigma surrounding HIV. In that case, the problem of stigma on HIV and AIDS has been solved by stigmatizing homosexuality into nonexistence.

It can be concluded that African theologians, in their work on HIV and AIDS, largely keep silent on homosexuality, primarily because they consider it to be irrelevant in face of the African epidemic, but also because of strategic considerations. Heteronormativity and Christian sensibilities are the major drivers behind the silences in the works of those theologians who have done groundbreaking work in the area of HIV and AIDS, but without taking into account same-sex practices and their eventual contribution to the transmission of HIV. As will be shown later in this article, there are a few noteworthy exceptions of theologians who recently have broken the silence on homosexuality, among others as a result of the HIV epidemic. Nyambura Njoroge (2008), for example, has stated that the reality of HIV forces African theologians "to make an U-turn in their teaching and theologizing": (p. 119) they need to discuss and reflect upon topics they would not dare to study before, including homosexuality. However, before discussing these emerging voices we will draw attention to those theologians who have taken it upon themselves to publicly condemn same-sex practices and relationships.

\section{REJECTING HOMOSEXUALITY BECAUSE OF AFRICAN CULTURE}

Although homosexuality is hardly discussed in the theological discourse on HIV and AIDS, there are other discourses in which African theologians explicitly address the issue. To a major extent, these discourses are in line with the anti-homosexual rhetoric that can be found in political and Christian discourses in postcolonial Africa.

A clear case in point is the special issue on homosexuality of the Catholic theological journal African Ecclesial Review (AFER). The editor sets the tone in his editorial, where he states: "In Africa, homosexuality is a taboo discussed in hushed tones. It is a distortion and a betrayal of marriage worldwide. Homosexual unions do not in any way contribute to the common good of humanity, as they are anti-life, anti-social and anti-Scriptural" (Nabushawo, 2004, p. 293). Another example of opposition against homosexuality is the volume Biblical View of Sex and Sexuality from African Perspective, published by the Nigerian Association for Biblical Studies. Several issues are discussed in the articles in this volume, but a major concern is homosexuality. According to the editor, the issue of homosexuality illustrates "that the rapid social change in Africa influenced by Western culture has negatively 
affected morality in Africa" (Abogunrin, 2006, p. 5). It appears from these publications, that the concern with homosexuality is informed by the increasing manifestation of homosexuality and the emerging gay and lesbian rights lobby that the authors observe in contemporary Africa. The authors explain this development from modernization and globalization, which would bring Western secular individualistic understandings of sexual autonomy to African contexts. For example, Chukwu (2004) argues, "Today, many people are arguing in favour of individuals' own sexual freedom and the need to defend the right of individuals in choosing their own preferred form of sexuality - be it heterosexuality or homosexuality. The result of this development is that the issue of homosexuality has come out of its cocoon and has assumed a central position in the arena of moral reasoning. As a result, there has been a wave of African abhorrence - a conflict of the traditionally entrenched heterosexual lifestyle and the emerging demands for overt homosexual lifestyles in the modern African society" (p. 296). Apparently homosexuality has become central in the African "arena of moral reasoning," and the authors of the above mentioned and other African theological publications take a firm position in this arena. They strongly oppose the "emerging demand for overt homosexual lifestyles," mentioned by Chukwu. Therefore, they employ biblical, theological, and cultural arguments.

\section{Biblical, Theological, and Cultural Arguments}

With regard to biblical arguments, the well-known apparently antihomosexual bible verses are cited frequently. On top of the editorial in the AFER issue, a bible verse from Leviticus 20:13 is cited. Here, "the man who has intercourse with a man in the same way as with a woman" is sentenced to death. This verse, and other biblical passages on homosexuality, are used to argue that homosexuality biblically is an "abomination" (cf. Gwamna, 2006, p. 5; Igboin, 2006, 345). The idea that these passages are historically, socially, and culturally limited and, hence, may not fully refer to contemporary practices is not considered in these arguments. Apart from this strict biblical argument, also theological arguments are employed. These are often based on an interpretation of Genesis 1 and 2, the creation stories. The authors of the AFER issue generally appeal to the Catholic perception of Christian marriage as a sacramental relationship that allows for the complementarity between man and woman. Hence, they approve of the official Catholic view that homosexual relationships are "intrinsically evil and seriously disordered" (Njino, 2004, p. 354). They consider it to be the vocation of the church to defend the institution of marriage against homosexuality (Tumwesigye, 2004). Likewise, Magesa (2005) points to the "essential complementarity" of man and woman because of the "innate sexual qualities which God has endowed each sex" (p. 100). Hence, he argues that "homosexuality falls short: not only on the biological level, but more essentially on the psychological and spiritual levels. If homosexuality means the total rejection of either woman or man, or either feminine or masculine, then one must say that it is theologically and spiritually seriously flawed" (p. 100). Magesa makes this comment in an article about African 
women's theology, in order to illustrate the danger of feminist approaches that neglect the fundamental difference between man and woman. Clearly, the argument of complementarity is informed by a patriarchal and heteronormative ideology of gender and sexuality which, with a reference to creation, is presented as being natural.

Apart from these biblical and theological arguments, the authors time and again refer to African culture to support their opposition against homosexuality. Significantly, they do not represent homosexuality as a Western, un-African invention, as often is done in popular discourses on homosexuality in Africa. It is acknowledged that "homosexuals must have existed in traditional Africa, [and] that they are still among us" (Chukwu, 2004, p. 295). Abogunrin (2006) states that "homosexuality is common to certain areas of Africa," but he suggests that it is "linked with adherents of a particular religion and ... . [has] been imported with that religion" (p. 12) - which probably is a reference to Islam. Although present in African societies for a longer time, homosexuality is said to be manifested more and more in recent days due to modern influences from the West. This development has raised the concern of most authors. Several theologians in their discussion on homosexuality distinguish between Western and African values. Referring to a Western individualistic ethics of sexual freedom that accepts homosexuality as a morally acceptable lifestyle, they point out that in Africa sexuality and relationships are not just an issue of the individual but of the community. Furthermore, they say that in Africa sexuality and relationships would not just serve for pleasure but to reproduce life in the community. This cultural worldview does not allow homosexuality, so it is stated frequently. Rather, from this worldview homosexuality is considered "an antithesis to life" (Kahiga, 2004) and for that reason it is said to be "morally unacceptable in Africa" (Chukwu, 2004, p. 312). In line with this argument, African woman theologian Constance Shisanya (2002) refers to the cultural taboo on homosexuality to underline the prophetic role of the church in Africa to condemn homosexuality.

The aforementioned idea of complementarity is explained by theologian Benezet Bujo in relation to the communal dimension that would characterize traditional Black Africa. According to Bujo (2003), "south of the Sahara, the fundamental anthropological conception in Africa is both bipolar and tripolar. One is a human being only in the duality of man and woman, and this bipolarity generates the triad man-woman-child, which leads to full community. Against this background, a man-man or woman-woman relationship would not only be looked on as an egoistic isolationism which dares not take the step of full human existence; it also leads to a sexist discrimination against part of the human race and shows an unwillingness to accept the enrichment that comes from heterogeneity" (p. 25). In his influential book, Bujo seeks to explore the foundations of an African ethic as part of the project to articulate a truly African type of Christianity. Clearly, for Bujo and many other African theologians, this ethic does not leave any space for the acceptance of homosexual relationships. 


\section{Inculturation Against Homosexuality}

In light of the interest of the present article, it is significant that in the discussion on homosexuality and African culture also the concept of inculturation is employed. Ferdinand Nwaigbo (2004) calls for authentic inculturation, meaning that churches have to appreciate and promote the "African values of human sexuality and family life" (p. 336). Concretely, this will involve, he says, " "the transformation of the mindsets of the homosexual persons through the African matrix, by making them available in the context of Christian marriage" (p. 336). Clearly, the reference to African values serves here to oppose homosexuality, with the implicit suggestion that homosexuality (maybe not empirically but) principally is un-African. Hence, the Western claim that homosexuality is a human rights issue is contested by Nwaigbo. He considers it to be part of the project of inculturation theology to resist the Western values and to foster the African ones and, thus, to oppose an eventual acceptance of homosexuality in African societies. In line with this, Gwamna (2006) proposes a theology of marriage and sex in Africa, which takes seriously that homosexuality, just like adultery and bestiality, is an abomination, according to the Bible as well as African tradition. This theology, according to Gwamna, is inculturated when it restores the tradition of marriage and family life in Africa in line with the "essential Christian values of marriage," such as "the communitarian aspect of marriage, the value of preserving life, respect for human sexuality" (p. 43). Another author employing inculturation theology to oppose homosexuality is John Walligo. Specifically addressing the challenge of HIV and AIDS to African theology, he argues that inculturation requires identification and promotion of genuine African values and practices that could be helpful to defeat the HIV epidemic, as well as to identify and oppose the values and practices that are critical to HIV and AIDS. Giving examples of the latter, he refers to cultural practices like widow inheritance, polygamy, incest and rape, and to the "negative globalization aimed at promoting homosexuality, lesbianism and bisexuality in Africa and elsewhere" (Walligo 2006, p. 296; emphasis original). Significantly, Walligo presents these issues not only as being against African culture and Christian teaching but also against "the demands of human rights and the equality of men and women" (p. 295). Thus, from the perspective of his inculturation theology, the rejection of homosexuality meets the demands of human rights and gender equality! Unfortunately, he does not explore this perception. His argument echoes some African critique on the perceived Western bias of the universal declaration of human rights, and the proposals for an African human rights charter. The latter would draw from the genuine African values mentioned by Walligo, being the central concern for life, family values and community values - which in his perception do not allow homosexuality.

Many authors referred to above, in their account on homosexuality as conflicting with African cultural perceptions of sexuality and marriage, refer to the book of Kenyan theologian John Mbiti entitled, African Religions and Pbilosopby (1990). This book, which has been foundational to African theologies of inculturation, includes a chapter on marriage and procreation where Mbiti explores the sacred function sexuality has in the worldview of African peoples. In this context, he mentions that homosexual relationships, just as fornication, incest, rape, bestiality 
and so on, are considered as sexual offences" (Mbiti, 1990, p. 144). Mbiti elaborates on this brief reference to homosexuality in his Love and Marriage in Africa (1973), where he discusses homosexual and lesbian relationships in the category of sexual perversions and deviations, together with bestiality, prostitution, concubinage, and rape. According to Mbiti (1973), "having sexual intercourse or intimacy with a person of the same sex is immoral, abnormal, unnatural, and a danger to society" (p. 35). The reason for this is that "two people of the same sex cannot establish the kind of relationship which can only come from a husband and wife relationship. No family life can arise between homosexuals or lesbians" (p. 218). Further, he argues, sexuality and relationships from an African culturalreligious perspective have a creative meaning: "It is on the creative dimension of marriage that you in fact become co-creator with God. In procreation you are fostering God's creative work in the world" (Mbiti, 1973, p. 43). As homosexual relationships do not have such a creative meaning (which, thus, in fact, is only about biological procreation) they are considered as not acceptable. A similar perception has been expressed by Laurenti Magesa from Tanzania, who emphasizes that sexuality, in the view of African religion, must transmit the "vital force of life" (p. 115). Hence, Magesa (1997) explains that "active homosexuality is morally intolerable because it frustrates the whole purpose of sexual pleasure and that of a human person's existence in the sight of the ancestors and God" (p. 146).

The books of Magesa (1997) and Mbiti (1990) on African traditional religions are influential in African theology, especially with regard the perception of African culture or African tradition. The accounts on sexuality and marriage in these books are reflected in the above outlined discourses on homosexuality and are used to oppose contemporary expressions of homosexuality in African societies. This is especially the case with theologians engaging in the paradigm of inculturation. Apparently, when it comes to the issue of homosexuality, inculturation theologies tend to be quite conservative and employ a static concept of culture. The culturalreligious values that did not allow for homosexuality in the past are simply reiterated and are uncritically applied to the present. Of course, the values taken from culture correspond with, and are reinforced by, the values that the theologians derive from the Bible and the Christian tradition. In this type of African theological discourse, cultural, biblical, and theological arguments converge in a unified stance toward homosexuality that is presented as an invention from the secular and liberal West. Clearly, these discourses, that largely fit in the paradigm of inculturation, follow the pattern of homosexuality being used in the postcolonial identity politics of Africa vis-à-vis the West.

African women theologians have pointed out that the convergence of cultural and Christian traditions, which inculturation theology seeks to mediate, easily results in African Christian women being trapped between the canons of African culture and Christianity (Masenya, 2003). Both canons support patriarchy and, thus, put women in a situation of double oppression. It appears from this section that not only women but also people engaged in same-sex relationships and those identifying as homosexual are trapped between the canons of culture and Christianity. These canons are not only used to legitimate patriarchy but also 
heterosexism and homophobia. Theologians working in the paradigm of inculturation theology are hardly sensitive to this, but rather tend to reinforce popular anti-homosexual rhetoric by fuelling it with arguments.

\section{EMERGING TOLERANT VOICES}

In the above sections, we have shown that silence and outright rejection constitute two of the dominant trends and trajectories of African theological discourses on homosexuality. Certainly, these trends are the most dominant ones at present. However, recently some voices have emerged that express more tolerant attitudes towards homosexuality. Many of these voices are from women theologians. However, first, Desmond Tutu must be mentioned.

When there is one person, and not the least one, who clearly contradicts the general observation that African theologians have taken up the cudgels against gay rights, it is the former Anglican archbishop from South Africa. ${ }^{3}$ According to his biographer, Tutu has become "perhaps the world's most prominent religious leader advocating gay and lesbian rights" (Allen, 2008, p. 372). This cannot be understood outside of Tutu's engagement with African theology, specifically liberation and Black theology. Although Tutu is currently known as a prominent African religious leader, in the 1970s and 1980s, he made an important contribution to Black theology, the South African counterpart of African liberation theology. As a South African Black theologian during Apartheid, his major theological concern was the recognition of the full humanity and the rights of Black people and their inclusion in the church and the society. In the postApartheid era, Tutu has engaged more and more with the issue of homosexuality. For him, both struggles are closely connected. As he says, "If the church, after the victory over apartheid, is looking for a worthy moral crusade, then this is it: the fight against homophobia and heterosexism. I pray that we will engage in it with the same dedication and fervor which we showed against the injustice of racism, so that we may rehabilitate the gospel of Jesus Christ" (Tutu, 1997, p. x). It has been crucial that Tutu came to understand homosexuality as an immutable characteristic like race and gender rather than a choice. This essentialist perception brought him to the conclusion that "discrimination against gays and lesbians was as wrong as that against blacks or women" (Allen, 2008, p. 372). Tutu has not elaborated his theological view on homosexuality. He just preaches and embodies his simple (but powerful) theology of Jesus siding with those who are pushed aside, and of God who accepts all people in the divine family. Hence, he calls on churches to be inclusive and welcoming of all, rather than making homosexuals "outcasts and pariahs on the basis of something which, like race or gender, they could do nothing about - their sexual orientation" (Tutu, 1997, p. x). The impact of Tutu's theological acceptance of homosexuality and his recognition of the rights of gays and lesbians seems to be limited as far as African theology is concerned. Even in South Africa, Tutu's Anglican Church does still not allow homosexual practices. Furthermore, there are hardly Black or liberation theologians of a younger generation which have engaged explicitly with the issue of homosexuality. Maybe 
this is to be explained from the malaise in Black and liberation theology in (South) Africa in the post-Apartheid and postcolonial era (cf. Chitando, 2009, pp. 78, 81). Apart from this crisis, it also could be that African Black and liberation theologians have difficulty to discuss issues of both sexuality and homosexuality. This is in line with the difficulty they have to discuss issues of gender and to dialogue with African women theologians (cf. Maluleke, 2001a), and it is in line with the difficulty of Latin American liberation theology to apply its major concern of justice on issues regarding sexuality (Althaus-Reid, 2009).

\section{Contribution of African Women Theologians}

In African theology, women theologians organized in the Circle of Concerned African Women Theologians have broken the silence on issues related to gender and sexuality, especially as far as these are oppressive to women. They express a firm critique of patriarchy as it is manifested in African cultures, religions and societies. Does this make African women theologians also more sensitive to the heteronormativity in these cultures, religions, and societies, and are they more open minded when it comes to homosexuality? Clearly, this is not the case with all African women theologians, as the above reference to Shisanya (2002) indicates. Most women theologians seem to take heterosexuality as normative and sometimes they use homophobic language. Although they critique patriarchy as a sexist ideology that is oppressive to women, they do not realize that it also is a heteronormative ideology that is oppressive to people engaged in homosexual relationships. Having said this, we want to acknowledge that some of the most prominent African women theologians have paid some attention to homosexuality in a progressive way and are coming to contest the anti-homosexual rhetoric in African Christian, theological, and political discourses.

A good example is an article of Mercy Oduyoye from Ghana, who is the founding mother of African women's theology. In the article entitled "A critique of Mbiti's view on love and marriage in Africa," Oduyoye (1993) critically responds to Mbiti's perception of love and marriage in African cultures. She agrees with Mbiti's view that marriage in the African worldview serves procreation and the transmission of life to the community, and like Mbiti she finds it understandable that from this background African cultures have great difficulty with homosexuality as well as with childlessness. According to Oduyoye, both these phenomena obviously "cut at the roots of Africa's main reason for sustaining the heterosexual marriage institution - children" (p. 355). However, Oduyoye differs from Mbiti in the evaluation of African cultures at this point. She strongly critiques Mbiti for relaying cultural perceptions that consider homosexual relations as a "sexual perversion" and she says to be "horrified by the demonization of homosexuals" she observes in Africa (p. 354). In line with African women's theology, Oduyoye evaluates culture far more critically than male theologians in the inculturation paradigm such as Mbiti tend to do. Employing a critical cultural hermeneutic, women theologians denounce the aspects of African cultures that are oppressive to women (cf. Kanyoro, 2002). Among these aspects is the perception of marriage as serving primarily procreation, as this leads to the objectification of women's 
bodies and to an identification of femininity with motherhood. Oduyoye, being childless herself, knows how oppressive this perception can be. This may explain the sense of solidarity with homosexuals that she expresses. In her opinion, both "homophobia and the phobia of childlessness" might be culturally understandable but yet poses a challenge to rethink the purpose of marriage and to re-understand what it means to contribute productively to the community ( $\mathrm{p}$. 355; see also Oduyoye, 1999). As far as we know, Oduyoye in more recent publications has not touched on the sensitive issue of homosexuality again. Yet, her discussion of the issue in dialogue with Mbiti can be considered as groundbreaking, not just because of the rejection of homophobia and the implicit acceptance of homosexual relationships, but because of the implied connection between the case of homosexuals and of women. Both run the risk of being trapped between the canons of African culture and the Bible.

Apart from Oduyoye, some other prominent African women theologians also can be found addressing homophobia and breaking the silence and taboo on the issue of homosexuality. As mentioned above, a widespread perception in Africa is that homosexuality is a Western phenomenon. Recently, Isabel Phiri, who was the continental coordinator of the Circle of Concerned African Women Theologians from 2002 to 2007, has begun to question this popular perception (Phiri, 2006). From her research among female sangomas in South Africa, she found that some of these traditional healers are engaged in same-sex relationships. Phiri (2006) offers two explanations for this: The sangomas would engage in same-sex relations, as these (different from heterosexual practices) do not require constant ritual cleansing, and because these relations would provide the sangomas with a way to deal with the trauma of sexual abuse in heterosexual relationships. Phiri draws an important conclusion from her empirical findings: "[T] relationships among the sangomas, ... may confirm the existence of this practice in Africa, independent of the incursion of Western civilization" (p. 126). This conclusion is particularly significant, as Phiri indicates, because sangomas are considered custodians of African culture. In the introduction of the volume in which the article was published, the editors (Phiri \& Nadar, 2006) acknowledge that, by touching on this sensitive issue, the silence is broken and the widespread perception of homosexuality as a Western phenomenon is contradicted. Phiri's brief discussion of homosexuality among the sangomas may be a beginning to open up a debate on homosexual relationships as part of African cultures and as an issue of equal value as the liberation of women and the pursuit of gender justice in the circle of African women's theology and of African theology at large.

A colleague of Phiri in the movement of African women's theology, Musa Dube from Botswana, is more explicit in her perception of homosexuality as a human rights and justice issue. Being originally a biblical scholar employing feminist and postcolonial hermeneutics, Dube more recently has been in the forefront of developing an African theological response to HIV and AIDS. Above, we referred to Nyambura Njoroge (2008), saying that the HIV epidemic forces theologians to make a U-turn, as they have to talk about controversial issues including homosexuality. Dube is one of the few theologians who has made this U-turn. In her book, The HIV and AIDS Bible (2008), she explores her understanding of the 
HIV epidemic as embedded in social epidemics of injustice. In that context, she mentions the discrimination of homosexuals together with poverty, gender inequality, ethnic conflict, and globalization as examples of the social injustices that fuel the HIV epidemic. A theological response to HIV and AIDS, according to Dube, should be concerned with these injustices rather than being preoccupied with people's sexual morality. It should be a liberation theology that seeks to liberate from all kinds of oppression and exploitative structures, and that promotes justice in individual relationships, societies and in the global world. Dube bases this theologically by referring to the account of creation. Creation, in her understanding, means that all life is sacred: "[A]ll people, regardless of their color, gender, class, race, nationality, religion, ethnicity, health status, age, or sexual orientation, were created in God's image and are loved by God, who is the source of human dignity" (p. 40). Where most theologians, as was explored above, share the perception of AIDS being a heterosexual epidemic in Africa and keep silent on homosexuality because it would be too controversial, Dube has broken this taboo. In the volume Africa Praying (Dube, 2003), with guidelines for HIV and AIDS sensitive liturgies in churches, she included a service on homosexuals. In this text, she states that homosexuality needs to be discussed because the taboo on the issue exposes men and women to HIV. Dube considers breaking the taboo and addressing the discrimination of homosexuals as a crucial part of a liberation theology of HIV and AIDS. Even more, she considers it necessary in order to embrace and celebrate the diversity created by God among humankind. By understanding homosexuality in this way, as a positive anthropological given, and by including the issue in her discourse of justice and liberation, Dube provides a theological basis for further discussion of homosexuality as a justice and human rights issue in African theology.

Finally, attention is to be drawn to a publication of Kenyan theologian Esther Mombo (2006). Mombo contributed to a volume with Anglican voices from all over the world speaking out on homosexuality, particularly on the homosexuality debate in the global Anglican Communion. In her piece of reflection, Mombo criticizes the selective use of the Bible in this debate by African Christians, as well as their moral hypocrisy as they blame Western Christians for being immoral while their own lives would be affected by Christian moral values only outwardly. Mombo also critiques African Anglican bishops for using the homosexuality issue as a way to avoid the real problems in their dioceses: "Issues of poverty, HIV / AIDS, theological education, women and children are pushed under the carpet while the flag of homosexuality is being flown high" (p. 151). Furthermore, she blames churches for demonizing and criminalizing homosexuals, what in her opinion forces these people "to hide their identity to marry wives and then to live with a double sexual life" (p. 151). Having phrased her firm critique, Mombo challenges churches to provide safe spaces, free of condemnation, "where we will listen to those who are of the gay and lesbian communities" (p. 152). Although she does not argue explicitly for the acceptance of homosexuality, Mombo's call for respect and love to homosexuals at least indicates a moderate and pastoral stance on the issue. Clearly, she is in opposition to the anti-homosexual rhetoric in African Christian discourses, and she firmly opposes the church politics played on the issue of 
homosexuality by African bishops in the Anglican Communion.

The voices of Tutu, a religious leader firmly rooted in African Black and liberation theology, and of some leading women theologians such as Oduyoye, Phiri, Dube, Njoroge, and Mombo, indicate that the silence and taboo on homosexuality has been broken. These voices are in the minority, but they certainly show that not all African theologians have taken up the cudgels against gay rights.

\section{TRENDS AND TRAJECTORIES: A CONCLUSION}

Two clear trends and trajectories appear from our analysis of African Christian theologians and their references to homosexuality. The first major trajectory is that the theologians who actively oppose gay rights generally employ arguments that fit in the paradigm of inculturation theology. They refer to the Bible and to African culture to argue that Christianity in Africa, if it seeks to be truly Christian and authentically African, cannot tolerate homosexuality. These theologians present us with a theological version of the popular discourses in Africa where homosexuality is represented as un-African and where African identity is constructed as exclusively heterosexual and as truly Christian vis-à-vis the liberal, secular, and morally inferior Western world. The theologians that are part of this trajectory - and most likely they are in the majority - confirm Epprecht's (2008) observation of African theologians who have taken up the cudgels against gay rights as part of African postcolonial identity politics. A fundamental question, in need of further research, is why precisely the issue of homosexuality is used to mark a sharp distinction between a perceived liberal and secular West and traditional African values.

The second trajectory, and a more recent trend, is that some dissident voices are heard, emerging from the tradition of liberation theologies, in particular African women's theology. These voices take a more tolerant stance towards homosexuality, show sympathy to the case of gays, lesbians and bisexuals in African societies, have questioned the various supposed bases for anti-homosexual rhetoric, and have provided some theological notions for further discussion on homosexuality and sexual diversity in African theology. To be clear, these voices are still firm in the minority: Only a very few African theologians have come to address homosexuality in a progressive way, and hardly any elaborate account on the issue has been published. Considering the dissident voices, it is significant to observe that, apart from Tutu, all are women. While African male liberation theologians of their generation seem to remain silent about homosexuality, some prominent women theologians have begun to break this taboo. Having discussed many controversial issues related to women's sexuality and oppression in terms of gender, African women theologians are the first to tackle the controversy surrounding homosexuality. They have begun to apply some of the central concepts in their theology, such as justice and liberation, to the case of homosexuals. This marks a major distinction from African male theologians working in the paradigm of 
liberation theology. Contrary to the example of Tutu, these theologians have not publicly addressed the issue of homosexuality but largely keep silent about it. Likewise, we have not yet come across a discussion of homosexuality by theologians engaged in the reconstruction paradigm, except for a condemning reference by Shisanya (2002). ${ }^{4}$ Dube (2001) has offered the critique that reconstruction theology is hardly concerned with the position and role of women in the reconstruction of African societies, and we are tempted to argue that this applies to the position of homosexuals as well.

To conclude, it is true that many African theologians have taken up the cudgels against gay rights. This applies in particular to those theologians engaged in the inculturation paradigm of African theology. Here, homosexuality is seen as incompatible with both African and Christian values. However, we have shown that some theologians, engaged in the liberation paradigm of African theology, have associated the topic of homosexuality with their major concerns of racism (Tutu) and gender inequality (Oduyoye, Phiri, Dube, and Mombo). Hence, they have come to discuss homosexuality progressively, informed by their commitment to liberation, justice and human rights. We do not want to suggest that these dissident voices are big in numbers and do increasingly influence public debates on homosexuality in African societies. The claim we want to make is far more modest, being that African theology is not a monolithic bloc opposed to homosexuality but rather includes some voices that break the social, cultural, and religious taboo surrounding homosexuality. Some African theologians have begun to develop concepts of African identity and African Christianity that are more inclusive to those who identify as homosexual. This conclusion is of major significance in light of the great controversy surrounding homosexuality in contemporary African societies, as it means that there are voices and arguments from within African contexts that oppose popular homophobic discourses and that develop a rather inclusive African Christian identity. The conclusion is also relevant in view of the huge chasm on homosexuality in world Christianity, which apparently is not simply a chasm between the global North and the global South, but a chasm of conservative and progressive voices in the multiple modernities of our globalizing postcolonial world.

\section{NOTES}

1. According to UNAIDS (2010), "[r]ecent studies show high levels of HIV infection among men who have sex with men. In Cape Town, South Africa, and Mombasa, Kenya, more than $40 \%$ of the adult population of men who have sex with men is living with HIV" (p. 3).

2. An exception is Constance Shisanya (2002), who suggests that women may be infected because their husbands are engaging in homosexual relationships.

3. Epprecht (2008) is aware of this, as he refers to Tutu and a few others as examples when he says: "Not all African religious leaders, for example, have aligned themselves with the homophobic extreme and, on the contrary, have taken big risks to denounce that extreme in unambiguous language” (p. 167). Yet, strange enough this is the only reference to Tutu in the whole book.

4. Shisanya's (2002) article is part of a volume that is published in the Theology of Reconstruction Series. 


\section{REFERENCES}

Abogunrin, S. O. (2006). Introduction. In S. O. Abogunrin (Ed.), Biblical view of sex and sexuality from an African perspective (pp. 3-14). Ibadan, Nigeria: Nigerian Association for Biblical Studies.

Allen, J. (2008). Desmond Tutu: Rabble-rouser for peace. The authorized bibliography. Chicago, IL: Lawrence Hill Books.

Althaus-Reid, M. (2009). "Let them talk. ..."” Doing liberation theology from Latin American closets. In M. Althaus-Reid (Ed.), Liberation theology and sexuality (pp. 5-18), London, UK: SCM Press.

Antonio, E. (2006). Introduction: inculturation and postcolonial discourse. In E. Antonio (Ed.), Inculturation and postcolonial discourse in African theology (pp. 1-28), New York, NY: Peter Lang.

Bearak, Barry. (2010). Malawi President Pardons Gay Couple. The New York Times, May 29, 2010. Retrieved December 5, 2011, from http://www.nytimes.com/2010/05/30/world/africa/30malawi.html

Bujo, B. (2003). Foundations of an African ethic: Beyond the universal claims of Western morality. Nairobi, Kenya: Paulines Publications.

Bujo, B., \& Muya, J. I. (2003). African theologians: The contribution of the pioneers (Part I). Nairobi, Kenya: Paulines Publications.

Bujo, B., \& Muya, J. I. (2006). African theologians: The contribution of the pioneers (Part II). Nairobi, Kenya: Paulines Publications.

Chitando, E. (2007). Living with hope: African churches and HIV / AIDS (Part 1). Geneva, Switzerland: WCC Publications.

Chitando, E. (2008). Religious ethics, HIV and AIDS and masculinities in Southern Africa. In N. Nicolson (Ed.), Persons in community: African ethics in a global culture (pp. 45-63). Scottsville, South Africa: University of KwaZulu-Natal Press.

Chitando, E. (2009). Troubled but not destroyed. Geneva, Switzerland: WCC Publications.

Chitando, E., \& Chirongoma, S. (2008). Challenging masculinities: religious studies, men and HIV in Africa. Journal of Constructive Theology, 14, 55-69.

Chitando, E., \& Gunda, M. R. (2007). HIV and AIDS, stigma and the liberation in the Old Testament. Exchange: Journal of Missiological and Ecumenical Research, 36, 184 197.

Chukwu, C. N. (2004). Homosexuality and the African culture. African Ecclesial Review, 46, 294-314.

Dube, M. W. (2008). The HIV \& AIDS Bible: Selected essays. Scranton, PA: University of Scranton Press.

Dube, M. W. (2001). Jesse Mugambi is calling us to move from liberation to reconstruction! A postcolonial feminist response. Unpublished paper.

Dube, M. W. (2003). Service for/ on homosexuals. In M. W. Dube (Ed.), Africa praying. A handbook on HIV / AIDS sensitive sermon guidelines and liturgy (pp. 209-214). Geneva, Switzerland: WCC Publications.

Dube, M. W., \& Kanyoro, M. (Eds.). (2004). Grantme justice! HIV / AIDS and gender readings of the Bible. Pietermaritzburg, South Africa: Cluster Publications.

Englund, H. (Ed.) (2011). Christianity and public culture in Africa. Athens, OH: Ohio University Press.

Epprecht, M. (1998). The "unsaying" of indigenous homosexualities in Zimbabwe: Mapping a blindspot in an African masculinity. Journal of Southern African Studies, 24, 631651.

Epprecht, M. (2008). Heterosexual Africa? The history of an idea from the age of exploration to the age of AIDS. Athens, OH: Ohio University Press. 
Frederiks, M. T. (2008). HIV and AIDS. Mapping theological responses in Africa. Exchange: Journal of Missiologicaland Ecumenical Research, 37, 4-22.

Frederiks, M. T., \& Mashau, T. D. (2008). Coming of age in African theology: The quest for authentic theology in African soil. Exchange: Journal of Missiological and EcumenicalResearch, 37, 109-123.

Gifford, P. (2009). Christianity, politics and public life in Kenya. London, UK: Hurst \& Co.

Gunda, M. R. (2010). The Bible and homosexuality in Zimbabwe: A socio-historical analysis of the political, cultural and Christian arguments in the homosexual public debate with special reference to the use of the Bible. Bamberg, Germany: Bamberg University Press.

Gwamna, D. J. (2006). Biblical teaching on marriage and sex: a case study of Leviticus $18 \& 20$. In S. O. Abogunrin (Ed.), Biblical view of sex and sexuality from Africanperspective (pp. 28-47). Ibadan, Nigeria: Nigerian Association for Biblical Studies.

Hassett, M. K. (2007). Anglican communion in crisis: How Episcopal dissidents and their African allies are reshaping Anglicanism. Princeton, NJ: Princeton University Press.

Hoad, N. W. (2007). African intimacies: Race, homosexuality, and globalization. Minneapolis, MN: University of Minnesota Press.

Igboin, B. O. (2006). A moral appraisal of homosexuality in biblical, Western and African worldviews. In S. O. Abogunrin (Ed.), Biblical view of sex and sexuality from African perspective (pp. 340-358). Ibadan, Nigeria: Nigerian Association for Biblical Studies.

Jenkins, P. (2007). The next Christendom: The coming of global Christianity, Oxford, UK: Oxford University Press.

Kahiga, J. (2004). Homosexuality: An antithesis to life. African Ecclesial Review, 46, 380385.

Kanyoro, M. R. A. (2002). Introducing feminist cultural hermeneutics. London, UK: Sheffield Academic Press.

Magesa, L. (1997). African religion: The moral traditions of abundant life. Maryknoll, NY: Orbis Books.

Magesa, L. (2004). Anatomy of inculturation: Transforming the church in Africa, Maryknoll, NY: Orbis Books.

Magesa, L. (2005). The challenge of African woman defined theology for the 21 st century. In N. W. Ndung'u and P. N. Mwaura (Eds.), Challenges and prospects of the church in Africa. Theological reflections of the 21st century (pp. 88-101). Nairobi, Kenya: Paulines Publications.

Maluleke, T. S. (2001a). African "Ruths," Ruthless Africas: Reflections of an African Mordechai. In M. W. Dube (Ed.), Other ways of reading: African women and the Bible (pp. 237-251). Atlanta, GA: Society of Biblical Literature 2001.

Maluleke, T. S. (2001b). The challenge of HIV/AIDS for theological education in Africa: towards an HIV / AIDS sensitive curriculum. Missionalia, 29, 125-143.

Maluleke, T. S. (2005). Half a century of African Christian theologies: elements of the emerging agenda for the twenty-first century. In O. U. Kalu (Ed.), African Christianity: An African story (pp. 469-493). Pretoria, South Africa: Department of Church History, University of Pretoria.

Martey, E. (2000). Liberation theologies: African. In V. Fabella and R. S. Sugirtharajah (Eds.), The SCM dictionary of third world theologies (pp. 127-129). London, UK: SCM Press.

Martey, E. (1993). African theology: Inculturation and liberation. Maryknoll, NY: Orbis Books.

Masenya, M. (2003). Trapped between two "canons": African-South African Christian women in the HIV/ AIDS era. In I. A. Phiri, B. Haddad \& M. Masenya (Eds.), African women, 
HIV / AIDS and faith communities (pp. 113-127). Pietermaritzburg, South Africa: Cluster Publications.

Mbiti, J. S. (1973). Love and marriage in Africa. London, UK: Longman Group Limited.

Mbiti, J. S. (1990). African religions and philosophy (2nd ed.). London, UK: Heinemann.

Mombo, E. (2006). Kenya reflections. In T. Brown (Ed.), Other voices, other worlds: The global church speaks out on homosexuality (pp. 142-153). New York, NY: Church Publishing.

Mugambi, J. N. K. (1995). From liberation to reconstruction: African Christian theology after the cold-war. Nairobi, Kenya: East African Educational.

Mugambi, J. N. K. (2003). Christian theology and social reconstruction. Nairobi, Kenya: Acton.

Murray, S. O., \& Roscoe, W. (Eds.). (1998). Boy-wives and female husbands: Studies in African homosexualities. New York, NY: St. Martin's Press.

Mutambara, M. (2006). African women theologies critique inculturation. In E. Antonio (Ed.), Inculturation and postcolonial discourse in African theology (pp. 173-192), New York, NY: Peter Lang.

Nabushawo, J. C. (2004). Editorial. African Ecclesial Review, 46, 293.

Nicolson, R. (2000). God in AIDS?, Five years later. Bulletin for Contextual Theology in Africa, $7(1), 10-12$.

Njino, J. (2004). Christian marriage in the era of homosexuality. African Ecclesial Review, 46, 339-365.

Nwaigbo, F. (2004). Homosexuality: A distortion of Christian marriage. African Ecclesial Review, 46, 315-338.

Njoroge, N. (2008). Beyond suffering and lament: Theology of hope and life. In D. C. Marks (Ed.), Shaping a global theological mind (pp. 113-120). Aldershot, UK: Ashgate.

Oduyoye, M. A. (1993). A critique of Mbiti's view on love and marriage in Africa. In J. K. Olupona \& S. S. Nyang (Eds.), Religiousplurality in Africa. Essays in honour ofJohn S. Mbiti (pp. 341-366). Berlin, Germany: Mouton de Gruyter.

Oduyoye, M. A. (1999). A coming home to myself: The childless woman in the West African space. In M. A. Farley \& S. Jones (Eds.), Liberating eschatology: Essays in honour of Letty M. Russell (pp. 105-120). Louisville, KY: Westminster John Knox Press.

Oduyoye, M. A. (2001). Introducing African women's theology. Cleveland, OH: The Pilgrim Press.

Phillips, O. (2004). The invisible presence of homosexuality: implications for HIV/AIDS and rights in Southern Africa. In E. Kalipeni, S. Craddock, J. R. Oppong, \& J. Ghosh (Eds.), HIV $\leftrightarrow A I D S$ in Africa: beyond epidemiology, Malden, UK: Blackwell.

Phiri, I. A. (2003). African women of faith speak out in an HIV / AIDS era. In I. A. Phiri, B. Haddad, \& M. Masenya (Eds.), African women, HIV / AIDS and faith communities (pp. 3-22). Pietermaritzburg, South Africa: Cluster Publications.

Phiri, I. A. (2004a). HIV/AIDS: An African theological response in mission. The Ecumenical Review, 56, 422-431.

Phiri, I. A. (2004b). Southern Africa. In J. Parrat (Ed.), An introduction to third world theologies (pp. 137-163). Cambridge, UK: Cambridge University Press.

Phiri, I. A. (2006). Dealing with the trauma of sexual abuse: A gender-based analysis of the testimonies of female traditional healers in KwaZulu-Natal. In I. A. Phiri \& S. Nadar (Eds.), African women, religion and health. Essays in honor of Mercy Amba Ewudziwa Oduyoye (pp. 113-130). Maryknoll, NY: Orbis Books.

Phiri, I. A., Haddad, B., \& Masenya M. (Eds.) (2003). African women, HIV / AIDS and faith communities. Pietermaritzburg, South Africa: Cluster Publications.

Phiri, I. A., \& Nadar, S. (2006). Introduction: “Treading softly but firmly.” In I. A. Phiri \& S. Nadar (Eds.), African women, religion and health: Essays in honor of Mercy Amba 
Ewudriwa Oduyoye (pp. 1-16). Maryknoll, NY: Orbis Books.

Shisanya, C. R. A. (2002). The impact of HIV/AIDS on women in Kenya. In M. N. Getui \&

M. M. Theuri (Eds.), Quests for abundant life in Africa (pp. 45-64). Nairobi, Kenya: Acton.

Tumwesigye, J. (2004). The church in defence of the institution of marriage against homosexuality. African Ecclesial Review, 46, 366-379.

Tutu, D. (1997). Foreword. In P. Germond \& S. de Gruchy (Eds.), Aliens in the household of God. Homosexuality and Christian faith in South Africa (pp. ix-x). Cape Town, South Africa: David Philip.

UNAIDS. (2010), Global report: Fact sheet sub-Saharan Africa. Geneva, Switzerland: UNAIDS.

van Klinken, A. S. (2011). The ongoing challenge of HIV and AIDS to African theology. Exchange: Journal of Missiological and Ecumenical Research, 40, 89-107.

Villa-Vicencio, C. (1992). A theology of reconstruction: Nation-building and human-rights. Cambridge, UK: Cambridge University Press.

Walligo, J. (2006). Inculturation and the HIV / AIDS pandemic in the AMECEA Region. African Ecclesial Review 48(1), 290-308.

Ward, K. (2002). Same-sex relations in Africa and the debate on homosexuality in East African Anglicism. Anglican Theological Review, 84, 81-111. 